\title{
Influence of Brand Awareness and Perceive Quality on Loyalty: The Mediating Role of Association in Traditional Medicine Market in Kumasi, Ghana
}

\author{
Peter Kwasi Oppong ${ }^{1}$, Solomon Tawiah Yeboah² \& Adelaide Gyawu ${ }^{3}$ \\ ${ }^{1}$ Cape Coast Technical University, Cape Coast, Ghana \\ ${ }^{2}$ BS. Abdur Rahman Crescent Institute of Science and Technology, Chennai, India \\ ${ }^{3}$ Cape Coast Technical University, Cape Coast, Ghana \\ p.oppong@cctu.edu.gh, soloty2002@gmail.com, akuagyawu@gmail.com
}

\begin{abstract}
Enhancing brand quality, association and awareness can generate greater loyalty which may lead to a sustainable edge in a competitive market. And yet, there is a relative paucity of studies on the influence of awareness and quality on loyalty via the mediating impact of association, particularly in the traditional health market. Hence, this study sought to investigate the influence of awareness and quality on loyalty via the intervening role of the association in the traditional health market. Based on Aaker`s customer-based brand equity framework, eight hypotheses were stated and examined through structural equation modelling. Data were gathered from a sample of 348 customers through systematic sampling. The research found that association perfectly mediates the path between awareness and loyalty, but plays a partial role in the path between perceived quality and loyalty. The study, therefore, contributes to advancing the limited branding literature in the traditional medicine industry. First, the study establishes the starring role of awareness, association, and quality as antecedents of loyalty in the context of brand management in the traditional medicine industry. Not only this but also the research confirms that association acts as a mediator in the relationships among awareness, association, quality and loyalty in the context of brand management in the traditional medicine industry.
\end{abstract}

Keywords: Herbal Medicine, Brand awareness, Brand association, Perceived quality, Brand loyalty, Customers.

\section{Introduction}

In recent decade, interest in plant medicines has been growing steadily globally, despite the extensive patronage of orthodox medicines for medical care. Herbal medicine consists of herbs, herbal materials, preparations, and finished herbal products, which comprise as active substances parts of plants, or other plant materials, or both (WHO, 2007). World Health Organisation (2008) reported that roughly 70\% to 80\% of the population in the industrialised world have consumed some kind of complementary or alternative medicine in their lifetime. Besides, WHO (2011) noted that approximately 70 to 95 percent of people residing in the developing world rely on herbal therapy to meet their health needs. In Ghana, a significant proportion of the population still patronise locally-manufactured herbal therapies for their primary health needs. The United Nations Development programme (2007) also revealed that nearly 80 percent of Ghanaians utilise herbal therapies for first-line treatment and basic health services. The herbal therapies are frequently used for the treatment of minor ailments, managing chronic diseases, and maintenance of fitness of health (Samojlik, 2013 cited by Naresh \& Reddy, 2016). With the ever-increasing use of herbal medicines and rapid expansion of the market, the development and production of local herbal medicines in Ghana have improved over the years in terms of product innovations and packaging.

Currently, the herbal medicines are certified by the Ghana Food and Drugs Authority (GFDA) and are usually bought as non-prescription medications. These medicines are sold in pharmacies, over-the-counter medicine shops, and herbal stores in the form of tablets, capsules, ointments, mixtures, and powders (Essegbey, Awuni, Essegbey, Akuffobea \& Mica, 2014). The rapid increase in the production of herbal medicines over the last few years has resulted in a keen rivalry in the traditional health industry. It has been noted that developing strong awareness, associations and high perceived quality can engender greater loyalty (Aaker, 1992), which can act as a barrier to competitive actions and customer-brand switching behaviour in the market (Kotler \& Pfoertsch, 2006). However, despite the essential role of awareness and perceived quality in building loyalty via the impact of association, there is a relative paucity of empirical studies to establish their importance to loyalty in the traditional health industry. Similar research conducted by Hyun and Kim (2011), however, focused on the mediated role of perceived quality on the influence of awareness on the association in the chain restaurant industry. For this purpose, this research aimed to assess how awareness and quality 
influence loyalty via the intervening role of the association in the traditional health industry. Hence, the objectives of this paper were to determine;

- The impact of awareness on association, loyalty, and quality in the traditional medicine industry in Kumasi.

- The impact of perceived quality on loyalty and association in the traditional medicine industry in Kumasi.

- The intervening role of association on the relationships among awareness, quality, and loyalty in the traditional medicine industry in Kumasi.

This paper, therefore, contributes to enhancing the currently limited branding theory in the traditional medicine industry. This paper confirms the importance of awareness, association, and quality as antecedents of loyalty in the discipline of brand management in the traditional medicine industry. Besides, the study establishes that brand association acts as a mediator in the relationships among awareness, quality, and loyalty in the discipline of branding management in the traditional medicine industry.

\section{Literature Review}

Brand Loyalty: Loyalty has been traditionally associated with fidelity and enthusiastic commitment to an individual, a cause, or a country. In the business context, however, loyalty relates to customers' preparedness to continue to patronise an organization for the long term, particularly on an exclusive basis, recommending the organization`s offering to others (Lovelock \& Wirtz, 2016). Alternatively, Kardes, Cronley and Cline (2011) described brand loyalty (BL) as an intrinsic commitment of customers to a brand. The authors further explained that loyalty comprises behavioural and attitudinal loyalty. Attitudinal loyalty measures the overall feelings a customer has toward a brand, whereas behavioural reflects customers' predisposition to repeatedly purchase a brand. Lovelock and Wirtz (2016) emphasised that loyalty does not only consist of behaviour but also preference, liking, and future intentions. Similarly, Ferrell and Hartline (2011) are of the view that BL consists of aspects of recognition, preference, and insistence according to its intensity.

In the authors'view, recognition is the least and occurs when a customer is familiar with the brand but does not have a strong desire to buy it. Brand preference, on the other hand, denotes a higher aspect of BL and here, consumers consider the brand first before any other rival brands. Finally, brand insistence indicates the topmost aspect of loyalty, is where customers do not accept the brand`s substitutes but expend much time and effort to look for the brand in the market. Kotler and Keller (2012) suggested that highly satisfied and loyal customers stay longer with a firm, buy more quantities of new and improved products, say positive things about the organization and its offering, are less responsive to rival brands and price hikes, and have lower costs relative to serving new customers because of the routine nature of their transactions. Greater customer loyalty base is also linked to high market share, price premium, competitive entry barrier, improved trade leverage, insulation against competitive actions and thus, contributing to the long-term profitability of a business (Aaker, 1996).

The Conceptual Model: Here, the conceptual model provides a graphical and narrative explanation of the key factors, and the hypothesised relationships among them in this research (Miles \& Huberman, 1994). In this research, brand awareness (BA) and perceived quality (PQ) are considered exogenous variables, while the brand association (BAS) is an intervening variable, and brand loyalty (BL) is an endogenous variable. Figure 1 displays the conceptual model of the research which posits that $B A$ and $P Q$ are directly related to BAS and BL. Also, it can be seen that BAS positively influences BL, whilst PQ is positively affected by BA. Finally, BAS mediates the relationships among BA, PQ, and BL. In this model, BA is operationalized as the strength of the brand residing in the potential buyer`s mind (Aaker, 1991), and comprised brand identification and recall (Keller, 2013). 
Figure 1: The Study`s Conceptual Model

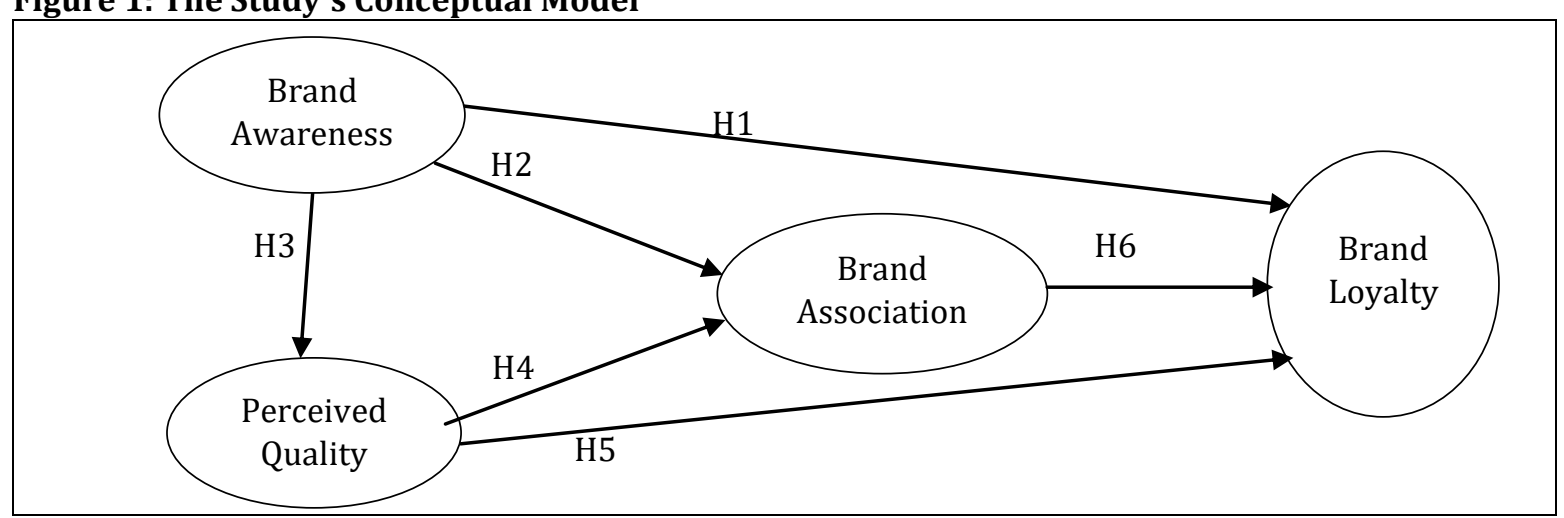

Source: Developed by the Researchers

Research Hypotheses: This paper seeks to evaluate the impact of BA and PQ on BL through the intervening role of the BAS in the traditional health market. Guided by the research conceptual model, the posited hypotheses are explained below.

Brand Awareness: Brand awareness is acknowledged as a salient brand asset that adds value to a firm`s offering (Aaker, 1996), and signifies the strength of a brand`s presence in the potential buyer`s memory (Aaker, 1991). Keller (2013) noted that the BA comprises recognition and recall. The recognition measures the customers' familiarity with the brand resulting from the prior exposures, whereas recall is the ability to retrieve the brand from the mind anytime the product class is mentioned (Hoeffler \& Keller, 2002; Aaker, 1991). Brand association is concerned with any aspect that the buyer associates with a brand, and is decomposed of perceived value, brand personality, and organizational associations (Aaker, 1996). Also, PQ is operationalised as a buyer's subjective evaluation of the overall superiority of an offering (Zeithaml, 1988), relative to its stated purpose and the alternatives (Aaker, 1991). Lastly, BL is also defined as customers` willingness to continue to patronise an organization for a longer-term, particularly on an exclusive basis.

Aaker (1991) however, contended that BA extends beyond recognition and recall to include top-of-mind awareness. Keller (2013) highlighted that BA contributes to the formation and strength of association. Moreover, consumers buy brands which they are familiar with, as they are usually recognised as reliable, of reasonable quality, and in business to stay (Aaker, 1991). A strong BA also positively affects the brand choice and supports the formation of loyalty (Ferrell \& Hartline, 2011; Aaker, 1996). Past studies also showed that strong BA strengthens association (Hyun \& Kim, 2011; Pike, Bianchi, Kerr, \& Patti, 2010), quality (Buil, Martinez, \& de Chernatony, 2013; Hyun \& Kim, 2011), and loyalty (Pike \& Bianchi, 2013). Hence, the following hypotheses are proposed:

H1: Brand awareness is significant and positively related to loyalty

H2: Brand awareness is significant and positively related to association

H3: Brand awareness is significant and positively related to perceived quality

Perceived Quality: Perceived quality is a major strategic thrust for many organizations because it has been shown to drive financial performance. Zeithaml (1988) described PQ as the subjective evaluation of the overall superiority of an offering. Aaker (1991) also defined PQ as the perceptions of the overall excellence of an offering to its intended use, relative to the other competing products. Perceived quality is not the same as product, objective, and manufacturing quality because it is based on consumer perceptions. Objective quality relates to the degree to which a product provides excellent service (Aaker, 1991); whereas product quality denotes the total attributes of a product that permit it to function as expected (Ferrell \& Hartline, 2011). In contrast, manufacturing quality also describes the conformance to manufacturing requirements (Zeithaml, 1988). It has been asserted that enhanced product quality can, however, increase the PQ (Gil, Andres \& Martinez, 2007).

Aaker (1991) suggested that the dimensions of PQ include performance, reliability, durability, serviceability, fit and finish, features, and conformance to specifications. Aaker (1992) highlighted that perceived quality can 
provide a platform for a higher market share, line extensions, a point of differentiation, high price, and ultimately, contributes to the overall profit margins of a company. A high PQ can also strengthen loyalty, future buying intentions (Aaker, 1992), and association (Chen, 2001; Campbell, 2002; Keller, 1993). Past studies also found that PQ positively influences BL (Hyun \& Kim, 2011; Gil et al., 2007). Hence, the following hypotheses are posited:

H4: Perceived quality is significant and positively related to association

H5: Perceived quality is significant and positively related to loyalty

Brand Association: Brand association is another essential brand asset that provides value for businesses (Keller, 2013), and refers to anything that consumers associate with a brand (Aaker, 1991), which conveys meaning to the potential buyers (Keller, 1993). Perceived value, brand personality, and organizational associations have been found in the literature as the antecedents of BA (Aaker, 1996; Buil et al., 2013). The perceived value measures the total subjective evaluation of the benefits consumers receive from a product relative to what is given out (Zeithaml, 1988), whereas brand personality is described as the package of human traits attached to brands (Aaker, 1997). The organizational associations relate to the aspects such as people, values, and programs of an organization connected to brands.

According to Aaker (1991), a favourable and unique association can be a source of differentiation, line extensions, and a basis for buying decisions, processing, and recall of product information, and can stimulate healthy attitudes and feelings towards a product. A strong association can increase loyalty (Aaker, 1991), and is positively affected by awareness and quality (Chen, 2001; Campbell, 2002; Keller, 2013). Past studies also revealed that association significantly influences loyalty (Hyun \& Kim, 2011; Gil et al., 2007). As a result, the following hypotheses are posited:

H6: Brand association is significant and positively related to loyalty

H7: Brand association mediates the relationship between brand awareness and loyalty

H8: Brand association mediates the relationship between perceived quality and loyalty

Research Design: Here, the plan used to test the hypotheses posited has been thoroughly discussed. Herbal medicines produced by Ghanaian firms and approved by the GFDA were included in this research. Besides, herbal stores in the Kumasi Metropolis licensed by the Traditional Medicine Practice Council (TMPC) were selected. Although, pharmacies and over-the-counter medicine shops are authorised to retail herbal and conventional medicines, recruiting participants from these shops was impossible. Consequently, herbal retail outlets were picked because they have been given authority by law to distribute only herbal drugs.

Population and Sampling Techniques: The research population comprised 80 certified herbal stores, 20 of them provide both wholesale and retail services, whilst 60 are engaged in only retailing. These data were obtained in 2018 from the TMPC, Kumasi. These stores are the licensed retail outlets where herbal medicines are sold as non-prescription medications. Using Krejcie and Morgan's (1970) framework for calculating sample size, 19 and 52 samples were picked from a total of 20 wholesale and 60 retail herbal stores respectively. The researcher then employed stratified sampling to choose the sample of the herbal stores in the Metropolis. This method allowed the research population to be divided into strata and elements of each stratum are randomly picked to ensure fair representation of each stratum in the research (Sekaran \& Bougie, 2016). Again, per the 2018 data of the 80 herbal stores, a total of 3710 customers above 18 years visit these stores daily to purchase herbal medicines in the Metropolis. Following the framework for calculating sample size, 348 customers were chosen as respondents in this research.

\section{Data Collection Instrument and Method}

A five-point Likert scale ranging from strongly agree (5) to strongly disagree (1) was utilised to ascertain the research participants` perceptions on BA, BAS, PQ, and BL of the herbal medicines sold in Kumasi. This type of questionnaire was used because the data collected permitted the use of statistics to analyse the data, while the interpretation is much easier (Creswell, 2014). The scale items of the research constructs were obtained from those that have been developed by earlier authors. The test responses of BA were adopted from Yoo, Donthu and Lee (2000), Tong and Hawley (2009), and Gil et al. (2007), PQ from Yoo et al. (2000), and Gil et al. (2007), BL from Aaker (1996), Tong and Hawley (2009), Gil et al. (2007), and Yoo et al. (2000), and BA from Netemeyer et al. (2004), and Aaker (1996). The questionnaires were administered to the customers at the 71 
shop floors via a systematic sampling method. As a result, the first participant was randomly picked, and later, every eleventh participant was asked to complete a questionnaire till the total sample got finished. This method was utilised because it provides a platform to recruit participants without first-hand information about the cases in the sample frame (Malhotra, Nunan \& Birks, 2017). In all, 348 questionnaires were distributed but 307 were usable due to invalid responses provided by some of the respondents.

Psychometric Measures of Scale Items: The reliability of the scale items was assessed by using individual item reliability and composite reliability of the constructs (Bagozzi \& Yi, 1998; Hair et al., 2014), while validity measures were determined by discriminant validity and convergent validity through Fornell and Lacker (1981) criterion and Average Variance Extracted (Bagozzi \& Yi, 1988) respectively. Table 1 exhibits the results of the psychometric measures of the research constructs. First, the individual items' reliability was evaluated through Cronbach`s alpha (Hair et al., 2014). The findings in Table 1 reveal that the Coefficient alpha values of BAS, BA, PQ, and BA were above the recommended threshold of 0.70 , which fall between .752 and .859, demonstrating evidence of reliability (Tavakol \& Dennick, 2011). Consequently, the scale measures were acceptable for evaluating the four variables.

Furthermore, due to the sensitive nature of the Coefficient alpha to the number of test responses resulting in under-estimation of reliability, composite reliability was computed to provide an appropriate assessment of the composite measure of the reliability of the latent variables in the measurement model (Hair, Sarstedt, Hopkins \& Kuppelwieser, 2014; Washburn \& Plank, 2002). The results of the composite reliability analysis also show that the coefficients of all the variables were higher than the proposed .70, falling between .751 and .860, indicating acceptable construct reliability (Fornell \& Larcker, 1981; Bagozzi \& Yi, 1988). Besides, the findings of the Average Variance Extracted (AVE) indicate that all the estimates are above the recommended .50, suggesting a high level of convergent validity (Bagozzi \& Yi, 1988). Also, by using the Fornell and Lacker (1981) criterion, the scores of the square root of the AVEs are well above the squared correlation coefficients between latent variables and any other latent variables, indicating superior discriminant validity.

Table 1: Results of Psychometric Measures

\begin{tabular}{lccccccc}
\hline Constructs & A & CR & AVE & BA & BAS & PQ & BL \\
\hline Brand Awareness (BA) & .761 & .760 & .515 & $.717^{*}$ & & & \\
Brand Association (BAS) & .753 & .774 & .537 & .383 & $.732^{*}$ & & \\
Perceived Quality (PQ) & .859 & .860 & .607 & .429 & .729 & $.779 *$ & \\
Brand Loyalty (BL) & .752 & .751 & .504 & .344 & .675 & .670 & $.709 *$ \\
\hline
\end{tabular}

Notes: $\mathbf{C R}=$ composite reliability; ${ }^{*}=$ Square root of AVEs; Off-diagonal estimates represent the squared inter-construct correlations

\section{Data Analysis and Results}

Demographic Characteristics of Respondents: Table 2 exhibits the results of the demographic profile of the research participants in relation to gender, age, and educational background. The results show that 208(68.4\%) of the respondents were male, whilst 96 (31.6\%) female. 18 to 25 years were 124 (40.7\%), 26 to 35 years were $115(37.7 \%), 35$ to 45 years were 33 (10.8\%), 46 to 60 years were 18 (5.9\%) and above 60 years were $15(4.9 \%)$. Besides, the participants who posses basic education were $39(12.7 \%)$, secondary education were 120 (39.2\%), diploma education were 62 (20.3\%), and tertiary education were 85 (27.8\%). The findings further revealed that a large percentage of the respondents were male, youth, and posses secondary education.

Table 2: Results of Respondents` Demographic Characteristics

\begin{tabular}{lll}
\hline Gender & Frequency & Valid Percent \\
\hline Male & 208 & 68.4 \\
Female & 96 & 31.6 \\
Total & 304 & 100.0 \\
Age (Years) & & \\
$18-25$ & 124 & 40.7 \\
$26-35$ & 115 & 37.7 \\
\hline
\end{tabular}




\begin{tabular}{lll}
\hline $36-45$ & 33 & 10.8 \\
$46-60$ & 18 & 5.9 \\
More than 60 & 15 & 4.9 \\
Total & 305 & 100.0 \\
Education Levels & & \\
Basic education & 39 & 12.7 \\
Secondary education & 120 & 39.2 \\
Diploma education & 62 & 20.3 \\
Tertiary education & 85 & 27.8 \\
Total & 306 & 100.0 \\
\hline
\end{tabular}

Structural Equation Modelling: To examine the hypotheses proposed in the research, covariance structural equation modelling (C-SEM) was employed because the data collected for this study contains multiple-scale items and latent variables which the traditional multiple regression procedures are considered not useful (Bryne, 2016). More importantly, C-SEM was used because it is an appropriate and efficient estimation method for testing a series of separate multiple regressions simultaneously, provides the overall model fit, and also accounts for measurement errors attached to the individual test responses (Hair et al., 2014; Bryne, 2016). The C-SEM was conducted in two phases as proposed by Anderson and Gerbing (1988). The measurement model through the confirmatory factor analysis was performed first before the path model.

Measurement Model: The measurement model was carried out through SPSS Amos 26 by using a maximum likelihood estimation method to confirm the loadings of the scale items on their intended constructs to produce $\mathrm{BL}, \mathrm{BA}, \mathrm{PQ}$, and $\mathrm{BAS}$. To attain satisfactory convergent validity, scale items with standardised regression weights below .50 were dropped (Hair et al., 2014), and consequently, three scale items were deleted. The analysis in Table 3 reveals that 13 scale items loaded on the four latent variables and all the regression weights proved to be significant, ranging from .594 and .822 , showing evidence of construct validity (ibid). Even though, the Chi-square test $\left(\mathrm{X}^{2}=143.717, \mathrm{df}=59, \mathrm{p}=.000\right)$ rejected the model, the Normed chi-square statistic (CMIN/DF) of 2.436 was below 3 which shows a better fit (Kline, 2015). The Root Mean Square Error of Approximation (RMSEA) of .069 with a 90\% confidence interval falls within .54 and .83 which also suggests a superior fit of the model (Bryne, 2016). Furthermore, Standardized Root Mean Square Residual (SRMR), Goodness-of-Fit Index (GFI) of .044 were less than .08, whilst the Goodness-of-Fit Index (GFI) and Adjusted Goodness-of-Fit Index (AGFI) of .935 and .900 also fall within the proposed limit of .90, which point to an acceptable model respectively (Hu \& Bentler, 1999). The Comparative Fit Index (CFI), NonNormed Fit Index (NNFI), and Incremental Fit Index (IFI) were .954, .939, and .954 were also above .90, demonstrating superior model fit respectively (Hu \& Bentler, 1999; Hair et al., 2014).

Table 3: Results of the Measurement Model

\begin{tabular}{lcc}
\hline Constructs and Test Items & Standardised Loadings & t-value \\
\hline Brand awareness & & \\
BW1 I know what X looks like & 0.719 & 10.023 \\
BW2 I can easily recognise X among other competing brands & 0.718 & 10.017 \\
BW7 I am very much aware of X & 0.715 & $-\mathrm{a}$ \\
Brand association & & $-\mathrm{a}$ \\
BA2 $\quad$ X gives me a reason to buy over other competing brands & 0.594 \\
BA4 I like the company which makes X & 0.794 & 10.193 \\
BA5 I trust the company that makes X & 0.794 & 10.193 \\
Perceived quality & & \\
PQ1 X is safe for use & 0.728 & $-\mathrm{a}$ \\
PQ2 X functions perfectly & 0.776 & 12.998 \\
PQ3 X is a very reliable product & 0.822 & 13.762 \\
PQ4 The quality of X is very high & 0.790 & 13.229 \\
Brand Loyalty & & \\
BL2 $\quad I$ would not buy other brands if X is available at the store & 0.659 & 9.853 \\
\hline
\end{tabular}


BL4 I am still willing to buy $\mathrm{X}$ even if its price is a little higher than that of competing brands $\quad 0.786 \quad 11.260$

BL5 I always buy X

0.679

- a

Notes: $\mathbf{X}=$ Focal brand; $\mathbf{a}=$ path parameter was set to 1 , therefore no $\mathbf{t}$-values were estimated; all loadings are significant at $\mathrm{p}<0.001$ level.

\section{Figure 2: Results of Path Diagram of Measurement Model}

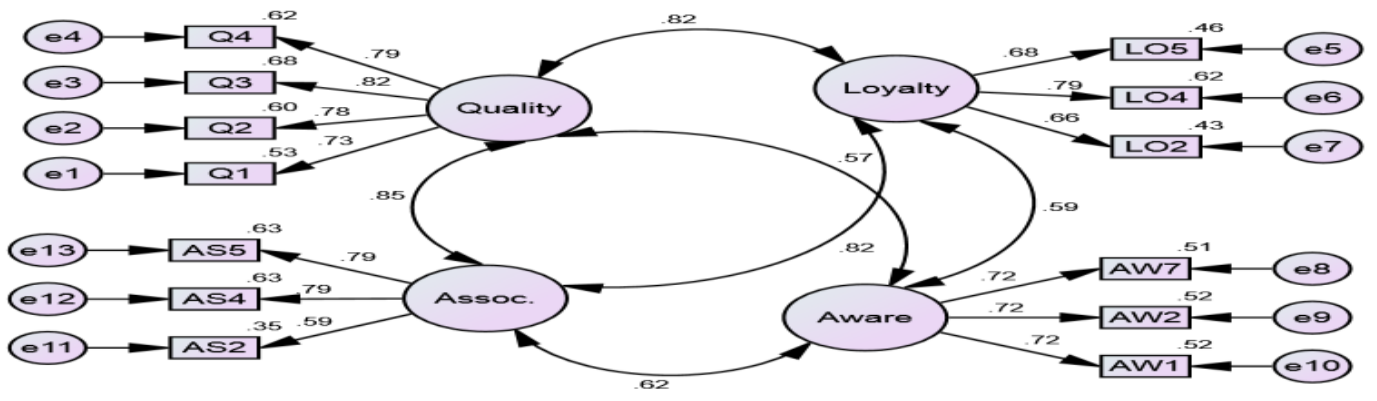

Path Model: The path analysis was conducted to assess the statistical significance of the hypothesised relationship between the latent variables in the research. Here, BA and PQ are exogenous constructs, whilst BAS is an intervening construct, and BL is an endogenous construct. Given the Chi-square statistics $\left(\mathrm{X}^{2}=\right.$ 143.717, $\mathrm{df}=59, \mathrm{p}<.001$ ), the other indices of the path model supported the path model; CMIN/DF = 2.436; $\mathrm{SRMR}=.044 ; \mathrm{GFI}=.935 ; \mathrm{AGFI}=.900 ; \mathrm{IFI}=.954 ; \mathrm{NNFI}=.939 ; \mathrm{CFI}=.954 ; \mathrm{RMSEA}=.069$. Table 4 exhibits the results of the path model which report that $B A(B=.200, t=2.872)$ and $P Q(B=.741, t=8.066)$ are significant and directly influence the BAS at $\mathrm{p}<0.001$, supporting $\mathrm{H} 2$ and $\mathrm{H} 4$ respectively. Besides, the results demonstrate that $\mathrm{BA}(B=.566, t=7.396)$ is significant and positively affects $\mathrm{PQ}$. This outcome confirms $\mathrm{H} 3$. However, the relationship between $B A(B=.101, t=.183)$ and $B L$ is positive but is statistically insignificant at $\mathrm{p}<.05$, and thus, $\mathrm{H} 1$ is not supported. Also, the path analysis demonstrates that $P Q(B=.415, t=3.006)$ and BAS $(B=0.405, t=2.629)$ are statistically significant and directly influence BL. These results also provide support to $\mathrm{H} 5$ and $\mathrm{H} 6$ respectively.

Table 4: Results of Path Model

\begin{tabular}{llllll}
\hline $\begin{array}{l}\text { Hypothese } \\
\text { s }\end{array}$ & \multicolumn{1}{c}{ Structural Relations } & $\begin{array}{l}\text { Standardised } \\
\text { Estimates }(\boldsymbol{\beta})\end{array}$ & $\begin{array}{l}\text { t- } \\
\text { value }\end{array}$ & $\begin{array}{l}\text { p- } \\
\text { value }\end{array}$ & Results \\
\hline H1 & Brand loyalty <------------ Brand awareness & 0.101 & 1.331 & 0.183 & $\begin{array}{l}\text { Not } \\
\text { supported }\end{array}$ \\
& & & & & \\
H2 & Brand association <-------- Brand awareness & 0.200 & 2.872 & 0.004 & $\begin{array}{l}\text { Accepted } \\
\text { H3 }\end{array}$ \\
Perceived quality <------ Brand awareness & 0.566 & 7.396 & 0.000 & Accepted \\
H4 & Brand association <------- Perceived quality & 0.741 & 8.066 & 0.000 & Accepted \\
H5 & Brand loyalty <---------- Perceived quality & 0.415 & 3.006 & 0.003 & Accepted \\
H6 & Brand loyalty <--------- Brand association & 0.405 & 2.629 & 0.009 & Accepted \\
\hline
\end{tabular}


Figure 3: Results of Path Diagram of the Structural Model

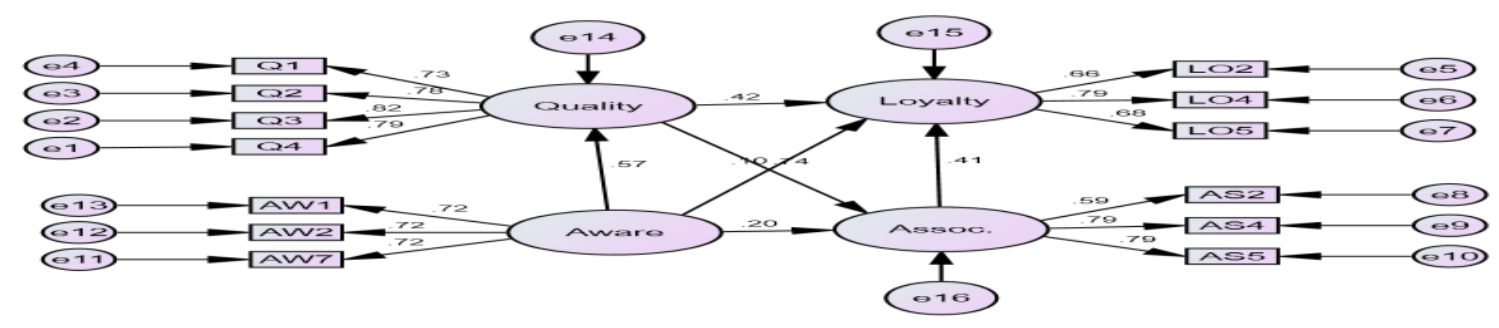

Test for Mediation: This paper also aimed to analyse the mediating effect of BAS on the path between BA and BL (H7), and between PQ and BL (H8). Baron and Kenny (1986) noted that a test for the mediational model involves a three-step approach; (1) regressing the mediator on the independent variable; (2) the dependent variable on the independent variable; and (3) the dependent variable on both the independent variable and the mediator. Guided by this approach, the mediational relationships were tested through a bootstrap re-sampling of 2000 and $95 \%$ bias-corrected confidence level. Table 5 exhibits the results of the test for the mediational model, which reveal that the direct relationship between $B A(B=.101, t=.956, p=$ .326) and BL is statistically insignificant at $p<.01$. However, the analysis also indicates that the indirect relationship between $B A(B=.486, t=4.089, p=.002)$ and $B L$ is significant at $p<.001$. These results demonstrate that BAS perfectly mediates the relationship between BA and BL. The outcomes of the analysis also show that the direct effect of $P Q(B=0.415, t=2.438, p=0.034)$ on $B L$ is significant at $p<.001$. The analysis also demonstrates that the indirect effect of $P Q(B=.300, t=2.216, p=.009)$ on $B L$ is statistically significant $\mathrm{p}<.001$. These indicate that BAS partially mediates the path between $\mathrm{PQ}$ and BL.

Table 5: Results of Mediating Test

\begin{tabular}{llllll}
\hline Hypotheses & Structural Relations & $\begin{array}{l}\text { Direct } \\
\text { without } \\
\text { Mediator }\end{array}$ & $\begin{array}{l}\text { Direct with } \\
\text { Mediator }\end{array}$ & $\begin{array}{l}\text { Indirect } \\
\text { Effect }\end{array}$ & Results \\
\hline H7 & $\begin{array}{l}\text { Loyalty<---Association<-- } \\
\text { Awareness }\end{array}$ & $.101(.326)^{* *}$ & $.200(.003)^{* *}$ & $.486(.002)^{* * *}$ & $\begin{array}{l}\text { Full } \\
\text { Mediation }\end{array}$ \\
H8 & $\begin{array}{l}\text { Loyalty <--- Association <--- } \\
\text { Quality }\end{array}$ & .415 & $.741(.001)^{* * *}$ & $.300(.009)^{* * *}$ & $\begin{array}{l}\text { Partial } \\
\text { Mediation }\end{array}$ \\
\hline
\end{tabular}

Notes: ${ }^{* *}=$ Not statistically significant; ${ }^{* * *}=$ Statistically significant

\section{Discussion of Findings}

The research sought to identify the impact of $B A$ and $P Q$ on BL via the mediated effect of BAS in the traditional health industry. This paper found that BA positively strengthens the PQ of herbal medicinal products in the traditional medicine market. This is consistent with the findings of prior studies (Buil et al., 2013; Hyun \& Kim, 2011), which indicate that a high level of BA significantly increases consumers' perceptions of brand quality. This outcome also supports the current literature (Aaker, 1992), which establishes that consumers usually associate high quality to well-known brands that generate a greater commitment to the brands. Besides, the research points out that BA enriches the beliefs registered in the minds of consumers about the brands sold in the traditional health market. This result is similar to the outcomes of earlier research (Hyun \& Kim, 2011; Pike et al., 2010), which demonstrate that awareness significantly enhances brand association. However, the results also indicate that consumers' awareness has no direct influence on their loyalty to the brands. This concurs with the results of the past study (Hyun \& Kim, 
2011; Im, Kim, Elliot \& Han, 2012), which found that BA does not have a direct impact on loyalty. Arguably, $\mathrm{BA}$ alone is not very powerful to create substantial value to enhance the loyalty of the brands.

In contrast, the findings of this research showed that awareness increased BL via the indirect impact of awareness and quality of the brands. This result strongly supported the position of earlier authors (Chen, 2001; Campbell, 2002; Keller, 1993), who contended that PQ is one of the vital aspects of BAS consumers linked to strong brands. Also, similar to the outcomes of the earlier research (Hyun \& Kim, 2011; Gil et al., 2007), this paper confirmed that favourable BAS directly affects customers` loyalty to brands in the market. Besides, consistent with the outcomes of past research (Hyun \& Kim, 2011), this paper found that a high level of PQ of plant medicines strengthens the BL in the market. Thus, customers are loyal to brands that appear to be of lower risk, reliable, and of high performance. The study also pointed out that, among the constructs, perceived quality $(\beta=0.741)$ has the greatest impact on loyalty. This supports the findings of a past study (Hyun \& Kim, 2011), which revealed that PQ has a stronger influence on loyalty compared to any assets of brand equity. Finally, the research also established that BA and PQ positively affect BL through the impact of the association in the traditional health market. These findings support the position of Aaker (1991) and Keller (1993) who proposed that the antecedents of strong brands with high equity interact.

\section{Conclusion and Recommendations}

Recommendations: Guided by the outcomes of the research, the following recommendations are made which have implications for the herbal practitioners in the industry.

- The results of this paper indicated that BA does not directly influence the BL of herbal medicinal products in the market. Therefore, traditional medicine practitioners need to design strategies to enhance the current level of awareness of their brands that will translate into the customer`s loyalty in the market.

- This paper also found that a high level of brand awareness positively affects the PQ and BA of herbal medicinal products. Hence, herbal practitioners should develop and exploit BA to strengthen the BAS and $\mathrm{PQ}$ of herbal medicines in the market.

- Moreover, this research established that BA strengthens loyalty through the intervening role of the association. As a result, herbal practitioners should consider BA and BAS as necessary pre-requisite to enhance BL in the plant medicine market.

- The research also revealed that PQ positively affects BL and BAS in the plant medicine market. To develop association and loyalty, traditional medicine practitioners should improve the perceived quality of herbal medicines.

- Besides, this paper confirmed that increased PQ of herbal therapies enriches the customers` loyalty partly due to the impact of association in the traditional health market. Consequently, to build loyalty, traditional medicine practitioners should enhance the PQ of herbal medicinal products along with association in the market.

Conclusion: This paper was set out to identify the influence of BA and PQ on BL via the intervening impact of BAS in the traditional health market. The results of this paper established that awareness enhances perceived quality and association. In this fashion, brand awareness is recognised as an essential initial step in developing a strong association and the perceived quality of brands in the traditional health industry. Besides, the outcomes of this paper confirmed that the relationship between BA and BL was positive but not significant. However, BA positively affects BL via the indirect impact of BAS. This suggests that, although BA is essential, it is not a sufficient condition to enrich BL in the traditional health market. The results of the study revealed that high $\mathrm{PQ}$ directly affects association in the traditional health market. Also, among the constructs, the findings indicated that $\mathrm{PQ}$ has the greatest impact on BL. Thus, $\mathrm{PQ}$ is considered a key antecedent of BAS and BL, which when enhanced can increase favourability of association and engender greater BL in the traditional health market. The outcomes of this paper also established that BAS partially mediates the impact of $\mathrm{PQ}$ on BL, but acts as a complete mediator on the influence of BA on BL. The study, therefore, concludes that BA, BAS, and PQ are the key antecedents of loyalty, and they interact to add value to a brand in the traditional health market. 
Limitations and Direction for Future Research: The methodology adopted to attain the objectives of this research was robust and sound but has limitations that necessitate future studies to improve upon its generalization. This research selected the herbal medicines produced by Ghanaian firms which did not include complementary or alternative medicines (CAM) that are considered foreign to the country`s culture. To enhance the generalisation of this research, future research should include both traditional herbal medicines and complementary or alternative medicines sold in the herbal shops in Ghana. Moreover, consumers who purchased herbal medicines from the in-store environment were selected as the participants in this paper but did not include those who buy from the market space. Future research should consider those who shop on the marketspace to improve on the generalization of this paper. Furthermore, the study employed quantitative research methods to determine the customer perceptions of PQ, BAS, BL, and BA of herbal medicinal products in the industry. Future research should consider using qualitative research methods to study the customers' perceptions of quality, BAS, BA, and BL in the traditional medicine market.

\section{References}

Aaker, D. A. (1992). The Value of Brand Equity. Journal of Business Strategy, 13(4), 27-32.

Aaker, D. A. (1991). Managing Brand Equity: Capitalizing on the Value of Brand Name. New York, N.Y. 10020: The Free Press.

Aaker, D. A. (1996). Measuring Brand Equity across Products and Markets. California Management Review, 38(3), 102-120.

Aaker, J. L. (1997). Dimensions of Brand Personality. Journal of Marketing Research, 34(3), 347-357.

Anderson, J. C. \& Gerbing, D. W. (1988). Structural Equation Modelling in Practice: A Review and Recommended Two-Step Approach. Psychological Bulletin, 103(3), 411-423.

Bagozzi, R. P. \& Yi, Y. (1988). On the Evaluating Structural Equation Models. Journal of Academy of Marketing Research, 16(1), 074-094.

Baron, R. M. \& Kenny, D. A. (1986). The Moderator-Mediator Variable Distinction in Social Psychology Research: Conceptual, Strategic, and Statistical Considerations. Journal of Personality and Social Psychology, 51(6), 1173-1182.

Buil, I., Martinez, E. \& de Chernatony, L. (2013). The Influence of Brand Equity on Consumer Responses. Journal of Consumer Marketing, 30(1), 62-74.

Bryne, B. M. (2016). Structural Equation Modelling with AMOS: Basic Concepts, Applications and Programming, ( $3^{\text {rd }}$ ed.), New York: Taylor \& Francis.

Campbell, M. C. (2002). Building Brand Equity. International Journal of Medical Marketing, 2(3), 208-218.

Chen, A. C. H. (2001). Using Free Association to Examine the Relationship between the Characteristics of Brand Association and Brand Equity. Journal of Product and Brand Management, 10(7), 439-457.

Creswell, J. W. (2014). Research Design: Qualitative, Quantitative, and Mixed Methods Approaches, (4 ${ }^{\text {th }}$ ed.), California: SAGE Publications Inc.

Dickov, V. \& Igić, S. (2013). The Aspect of Brands and Marketing Development in the Pharmaceutical Industry in Transition Countries. International Journal of Operations and Logistics Management, 2(4), 49-57.

Essegbey, G. O., Awuni, S., Essegbey, I. T., Akuffobea, M. \& Mica, B. (2014). Country Study on Innovations, Intellectual Property and Informal Economy: Traditional Medicines in Ghana, (13 th ed.), World International Property Organization, Geneva.

Ferrell, O. C. \& Hartline, M. C. (2011). Marketing Strategy, ( ${ }^{\text {th }}$ ed.). USA: Cengage Learning.

Fornell, C. \& Larcker, D. F. (1981). Evaluating Structural Equation Models with Unobservable Variables and Measurement Error. Journal of Marketing Research, 18(1), 39-50.

Gil, R. B., Andres, E. F. \& Martinez, E. S. (2007). Family as a Source of Customer-Based Brand Equity. Journal of Product \& Brand Management, 16(3), 188-199.

Hair, J. H. Jr., Black, W. C., Babin, B. J. \& Anderson, R. E. (2014). Multivariate Data Analysis, (7th ed.), England: Pearson Education.

Hair, J. H. Jr., Sarstedt, M., Hopkins, L. \& Kuppelwieser, V. G. (2014). Partial Least Squares Structural Equation Modelling (PLS-SEM): An Emerging Tool in Business Research. European Business Review, 26(2), 106121.

Hoeffler, S. \& Keller, K. L. (2002). Building Brand Equity through Corporate Societal Marketing. Journal of Public Policy and Marketing, 21(1), 78-89. 
Hu, L. \& Bentler, P. M. (1999). Cut-off Criteria for Fit Indexes in Covariance Structure Analysis: Conventional Criteria versus New Alternatives. Structural Equation Modelling: Multidisciplinary Journal, 6(1), 1- 55.

Hyun, S. S. \& Kim, W. (2011). Dimensions of Brand Equity in Chain Restaurant Industry. Cornell Hospitality Quarterly, 52(4), 429-437.

Im, H. H., Kim, S. S., Elliot, S. \& Han, H. (2012). Conceptualising Destination Brand Equity from a CustomerBased Brand Equity Perspective. Journal of Travel \& Tourism Marketing, 29(4), 385-403.

Kardes, F. R., Cronley, M. L. \& Cline, T. W. (2011). Consumer Behaviour. USA: Cengage Learning.

Keller, K. L. (1993). Conceptualization, Measuring and Managing Customer-Based Brand Equity. Journal of Marketing, 57(1), 1-22.

Keller, K. L. (2013). Strategic Brand Management: Building Measuring, and Managing Brand Equity, Global Edition, (4th ed.), England: Pearson Education.

Kline, R. B. (2015). Principles and Practice of Structural Equation Modelling, (2 ${ }^{\text {nd }}$ ed.), New York: Guilford Press.

Kotler, P. \& Keller, K. L. (2012). Marketing Management, (14th ed.). New Jersey 07458: Pearson Education Inc.

Kotler, P. \& Pfoertsch, W. (2006). B2B Brand Management. Germany: Springer (https://link.springer.com/content/pdf/bfm\%3A978-3-540-44729-0\%2F1.pdf: Accessed April 19, 2019).

Krejcie, R. V. \& Morgan, D. W. (1970). Determining Sample Size for Research Activities. Educational \& Psychological Measurement, 30, 607-610.

Lovelock, C. \& Wirtz, J. C. (2016). Services Marketing: People, Technology and Strategy, ( $8^{\text {th }}$ ed.), USA: Pearson Education Inc.

Malhotra, N. K., Nunan, D. \& Birks, D. F. (2017). Marketing Research: An Applied Approach, (5 ${ }^{\text {th }}$ Ed.). United Kingdom: Pearson Education Ltd.

Miles, M. B. \& Huberman, A. M. (1994). Qualitative Data Analysis: An Expanded Sourcebook, (2 ${ }^{\text {nd }}$ ed.), California 91320: SAGE Publication, Inc.

Naresh, B. \& Reddy, D. B. S. (2016). Impact of Perception on Customer Purchase Behaviour of Herbal Product in India. Indian Journal of Research, 5(6), 233-235.

Netemeyer, R. G., Krishna, B., Pullig, C., Wang, G., Yagci, M., Dean, D., Ricks J. \& Wirth, F. (2004). Developing and Validating Measures of Facets of Customer-based Brand Equity. Journal of Business Research, 57, 209-224.

Pike, S. D., Bianchi, C., Kerr, G. F. \& Patti, C. (2010). Customer-Based Brand Equity for Australia as a Long-Haul Tourism Destination in an Emerging Market. International Marketing Review, 27(4), 1-26.

Pike, S. \& Bianchi, C. (2013). Destination Brand Equity for Australia: Testing a Model of CBBE in Short-Haul and Long-Haul Markets. Journal of Hospitality \& Tourism Research, XX (X), 1-21.

Sekaran, U. \& Bougie, R. (2016). Research Methods for Business: A Skill-Building Approach, (7th ed.). United Kingdom: Wiley \& Sons.

Tavakol, M. \& Dennick, R. (2011). Making Sense of Cronbach`s Alpha. International Journal of Medical Education, 2, 53-55.

Tong, X. \& Hawley, J. M. (2009). Measuring Customer-Based Brand Equity: Empirical Evidence from Sportswear Market in China. Journal of Product \& Brand Management, 18(4), 262-271.

United Nations Development Programme. (2007). The Ghana Human Development Report: Towards a More Inclusive Society, Ghana (http://www.hrd.undp.org/sites/default/files/nhdr_ghana.pdf: Accessed July 7, 2019).

Washburn, J. H. \& Plank, R. E. (2002). Measuring Brand Equity: An Evaluation of a Consumer-Based Brand Equity Scale. Journal of Theory and Practice, 10(1), 46-62.

WHO. (2007). WHO guidelines for assessing the quality of herbal medicines with reference to contaminants and residues. Geneva, Switzerland: WHO Press.

WHO. (2008). Traditional Medicine. $\quad$ Fact $\quad$ Sheet (http://www.who.int/medicines/areas/traditional/definitions/en/pdf: Accessed June 4, 2019)

WHO. (2011). Traditional Medicines, Global Situation, Issues, and Challenges. The World Medicines Situation, (3ed.), Geneva (http://www.who.int/medicines/areas/policy/world_medicines_situation /WMS_ch6_wPricing_v6.pdf: Accessed June 14, 2019).

Yoo, B., Donthu, N. \& Lee, S. (2000). An Examination of Selected Marketing Mix Elements and Brand Equity. Journal of the Academy of Marketing Science, 28(2), 195-211.

Zeithaml, V. A. (1988). Consumer Perceptions of Price, Quality, and Value: Means-End Model and Synthesis of Evidence. Journal of Marketing, 52, 2-22. 